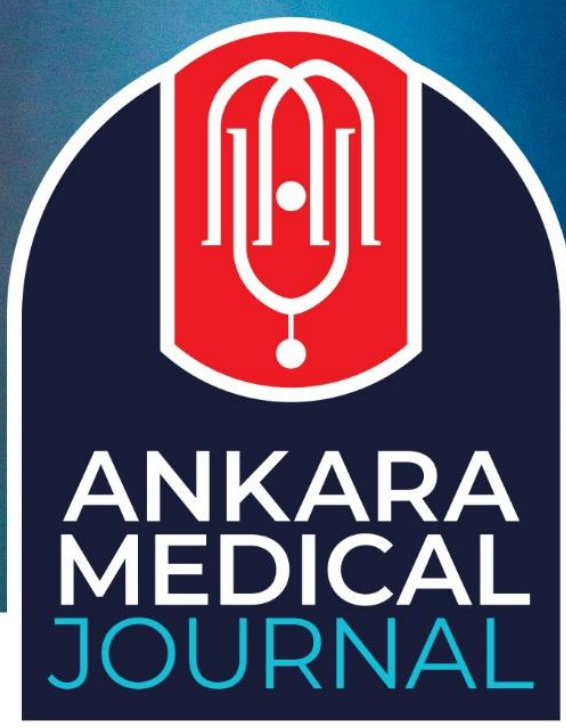

Research Article

Ankara Med J, 2020;(2):387-398 // 이 10.5505/amj.2020.59140

\title{
EVALUATION OF ANTHROPOMETRIC AND BIOCHEMICAL PROPERTIES OF PATIENTS WHO APPLIED TO OBESITY POLICLINICS
}

OBEZITTE POLIKKLINIIKLERINE BAŞVURAN HASTALARIN ANTROPOMETRIKK VE BİOKIMYASAL PARAMETRELERININN DEĞERLENDİRILMESİ

\section{Şennur Doğan1, (i) Cemil Işık Sönmez¹, (D) Duygu Ayhan Başer²}

1Department of Family Medicine, Düzce University, Düzce, Turkey

${ }^{2}$ Hacettepe University Medical Faculty, Department of Family Medicine, Ankara, Turkey

Yazışma Adresi / Correspondence:

Duygu Ayhan Başer (e-mail: duyguayhan@outlook.com)

Geliş Tarihi (Submitted): 17.07.2019 // Kabul Tarihi (Accepted): 26.05.2020

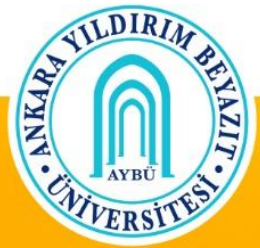

Ankara Yildıım Beyazıt University Faculty of Medicine 


\title{
Öz
}

Amaç: Bu çalışmada obezite polikliniğine başvuran hastaların antropometrik ve biyokimyasal özelliklerinin değerlendirilmesi ve karşılaştırılması amaçlandı.

Materyal ve Metot: Bu tanımlayıcı tipteki çalışmanın evrenini Ağustos 2016-Ekim 2017 tarihleri arasında obezite polikliniğine başvuran toplam 1650 hasta oluşturmuştur. Bu hastalar kayıtlardan retrospektif olarak taranmış ve BMI $\geq 25 \mathrm{~kg} / \mathrm{m}^{2}$ olan 925 hasta çalışmaya dahil edildi. Hastalar DSÖ'nün obezite sınıflamasına göre 4 gruba ayrılmış ve bu gruplara göre değerlendirme yapılmıștır. Hastaların antropometrik ölçümleri, Biyoelektrik Empedans Analizi ve laboratuvar sonuçları hasta dosyaları ve hastane veri tabanları taranarak elde edilmiştir. Verilerin istatistiksel analizi SPSS 23 programı ile yapılmıștır ve $\mathrm{p}<0,05$ anlamlı kabul edilmiştir. Bulgular: Katılımcıların \%84,3'ünü kadınlar olușturmuștur. Tüm antropometrik özelliklerde gruplara göre anlamlı olarak farklılık saptanmıştır. Hemoglobin, hematokrit, MCV, demir, ferritin ve D vitamini düzeyleri ile ortalama insülin, insülin direnci, kreatinin, ürik asit, AST, ALT ve TG değerleri erkeklerde anlamlı olarak daha yüksek saptanmıştır (her biri için p<0,001). Evre 1 obez bireylerin Hb, HCT, MCV, insülin, HOMA-IR, keatinin, ürik asit, AST, ALT, TG, demir, ferritin ve D vitamini değerleri diğer gruplardan anlamlı derecede daha yüksek; PLT ve HDL değerleri daha düşük saptanmıştır (her biri için $p<0,001$ ).

Sonuç: Obezitenin vücut bileşenleri ve biyokimyasal parametreler üzerindeki etkileri cinsiyete ve obezite derecesine bağlıdır. Obez hastalar değerlendirilirken BMI ile birlikte bel çevresi, kalça çevresi, vücut yağ miktarı ve biyokimyasal parametrelerin ölçümü de yapılmalıdır.

Anahtar Kelimeler: Antropometrik ölçümler, biyokimyasal ölçümler, biyoelektrik empedans analizi, vücut kitle indeksi, obezite

\begin{abstract}
Objectives: In this study, it was aimed to evaluate and compare the anthropometric and biochemical properties of patients who applied to the obesity outpatient clinic.

Materials and Methods: The universe of this descriptive study consisted of 1650 patients who applied to the obesity outpatient clinic between August 2016 and October 2017. These patients were retrospectively scanned, and 925 patients with BMI $\geq 25 \mathrm{~kg} / \mathrm{m}^{2}$ were included in the study. The patients were divided into 4 groups according to WHO's obesity classification and evaluated according to these groups. Anthropometric measurements, Bioelectrical Impedance Analysis, and laboratory results of the patients were obtained by scanning patient files and hospital databases. Statistical analysis of the data was done via SPSS 23 program, and $\mathrm{p}<0.05$ was considered significant.
\end{abstract}

Results: $84.3 \%$ of the participants were women. There was a significant difference in all anthropometric features compared to the groups. Hemoglobin, hematocrit, MCV, iron, ferritin, and vitamin D levels and mean insulin, insulin resistance, creatinine, uric acid, AST, ALT, and TG values were significantly higher in males ( $p<0.001$ for each). Hb, HCT, MCV, insulin, HOMA-IR, creatinine, uric acid, AST, ALT, TG, iron, ferritin, and vitamin D values of stage 1 obese individuals were significantly higher than other groups; PLT and HDL values were found lower ( $\mathrm{p}<0.001$ for each).

Conclusion: The effects of obesity on body components and biochemical parameters depend on gender and degree of obesity. While evaluating obese patients, waist circumference, hip circumference, body fat amount, and biochemical parameters should be measured together with BMI.

Keywords: Anthropometric measurements, biochemical measurements, bioelectric impedance analysis, body mass index, obesity. 


\section{Introduction}

Today, obesity is a rapidly growing public health problem affecting an increasing number of countries worldwide, including Turkey. The frequency of obesity is increasing due to unhealthy lifestyle habits such as high caloric intake and inadequate physical activity.

According to data from Turkey Health Survey 2016, the ratio of the pre-obese individuals over age 15 was $34.3 \%$, and the ratio of obese individuals was 19.6\%. In gender discrimination; $23.9 \%$ of women were obese, and $30.1 \%$ were pre-obese; $15.2 \%$ of men were obese, and $38.6 \%$ of them were pre-obese. ${ }^{1}$

According to the World Health Organization (WHO), excessive weight and obesity are defined as an abnormal or excessive amount of fat accumulation that poses a health risk. ${ }^{2} 15-18 \%$ of adult men's body weight and 20 $25 \%$ of women's body weight are composed of fatty tissue. Obesity causes this distribution to increase by $25 \%$ in men and $30 \%$ in women. ${ }^{3}$ Obesity shows differences between two gender, for example, patterns of fat distribution differ between men and women, visceral fat being predominant in men and subcutaneous fat being predominant in women. ${ }^{4,5}$

Obesity has negative effects on many parameters such as fasting blood glucose, insulin resistance, and cholesterol values. When not treated, it affects all of the organs and systems in the body, especially the endocrine and cardiovascular system. ${ }^{4}$ There is a relationship between obesity and type 2 diabetes mellitus, insulin resistance, hypertension, cardiovascular disease, hyperlipidemia, metabolic syndrome, cerebrovascular disease, cholecystitis, sleep apnea, osteoarthritis, hyperuricemia and gout and breast, gallbladder, colon, rectum, prostate cancers. ${ }^{5}$ Obesity causes a serious rise in morbidity and mortality as a result of many chronic diseases.

Many anthropometric indicators have been proposed to diagnose the health risks taking into account the increased body fat; the most widely used is still the Body Mass Index (BMI). However, other indicators have been recommended. ${ }^{3,5}$

Today, with preventive health policies, it is aimed to prevent many chronic diseases and reduce mortality by recognizing and treating obesity. ${ }^{6}$ Because of that aim, to compare the anthropometric and biochemical properties of patients according to BMI groups is much important.

Our main purpose in this study was to investigate the relationship of obesity according to BMI groups with anthropometric and biochemical parameters. 


\section{Materials and Methods}

In this descriptive study, archive data of 1650 patients who applied to Obesity Polyclinic of Family Medicine Department of a University between August 2016 and October 2017 were examined retrospectively. 925 patients with BMI $\geq 25 \mathrm{~kg} / \mathrm{m}^{2}$ were included in the study.

The data of age, gender, history, medications, anthropometric measurements, Bioelectric Impedance Analysis (BIA) measurements, and laboratory were provided from the patient records. Measurement and blood tests were performed at least 8 hours after fasting in the morning. Patients under 18 years of age, pregnant women, patients with pacemakers, type $1 \mathrm{DM}$ and type $2 \mathrm{DM}$ patients, antilipidemic drug users, patients with renal failure or liver failure, patients with myocardial infarction or stroke, patients with $\mathrm{BMI}<25 \mathrm{~kg} / \mathrm{m}^{2}$ and patients whose archival information cannot be reached have been excluded.

Patients were divided into 4 groups according to the WHO obesity classification. 25,0-29,9 BMI was pre-obese = group 1, 30-34,9 BMI was of stage 1 obese = group 2, 35-39,9 BMI was stage 2 obese = group 3 and BMI $\geq 40$ was stage 3 obese = group 4 .

Anthropometric and BIA measurements and biochemical analysis of the groups were investigated. Basal metabolic rate (BMR), body fat percentage (BFP), body fat tissue weight (BFTW), body lean tissue weight (BLTW), total body water (TBW), and visceral fat ratio (VFR) were calculated with BIA.

All data were transferred to the statistical program-SPSS 23.0- and analyzed. The normality assumption of continuous quantitative variables was made by Kolmogorov Smirnov test. Independent Samples t-test, Mann Whitney U test, Kruskal-Wallis (post hoc Dunn) test were used for comparison between groups. Pearson ChiSquare method was used to investigate the relationships between categorical variables. The significance level was accepted as 0.05 .

For the study, permission was obtained from a University Medical Faculty Clinical Research Ethics Committee with the decision number of 25.12.2017 and 2017/161.

\section{Results}

$780(84.3 \%)$ women and 145 men (15.7\%), a total of 925 patients were recruited. The distribution of individuals by groups; pre-obese (group 1) = 232 people (25.1\%), stage 1 obese (group 2) = 234 people $(25.3 \%)$, stage 2 obese (group 3) = 234 people $(25.3 \%)$ and stage 3 obese (group 4) = 225 people $(24.3 \%)$. The distribution of males and females by WHO obesity classification groups is shown in Table 1 . There was a 
significant difference between males and females, according to all WHO obesity classification groups ( $\mathrm{p}$ $<0.001)$.

Table 1. Distribution of males and females by WHO obesity classification groups

\begin{tabular}{|c|c|c|c|c|c|}
\hline & $\begin{array}{c}\text { Pre-obese } \\
\text { (group 1) } \\
\text { (n = 232 }\end{array}$ & $\begin{array}{c}\text { Stage } 1 \text { obese } \\
\text { (group 2) } \\
\text { (n = 234) }\end{array}$ & $\begin{array}{c}\text { Stage } 2 \text { obese } \\
\text { (group } 3 \text { ) } \\
(n=234)\end{array}$ & $\begin{array}{c}\text { Stage } 3 \text { obese } \\
\text { (group 4) } \\
(n=225 \text { ) }\end{array}$ & $\mathbf{p}$ \\
\hline Female & $193(24.74 \%)$ & $179(22.94 \%)$ & $202(25.89 \%)$ & $206(26.41 \%)$ & \multirow{2}{*}{$<0.001$} \\
\hline Male & $39(26.89 \%)$ & 55 (37.93\%) & $32(22.06 \%)$ & $19(13.10 \%)$ & \\
\hline
\end{tabular}

The median and interquartile range values of the anthropometric variables according to the males and females in the study are shown in Table 2.

Table 2. Comparison of median and interquartile range values of anthropemetric variables in males and females

\begin{tabular}{|c|c|c|c|}
\hline Parameter & $\begin{array}{c}\text { Female } \\
(n=780)\end{array}$ & $\begin{array}{c}\text { Male } \\
(n=145)\end{array}$ & $\mathbf{p}$ \\
\hline Age (Year) & $\begin{array}{c}40.00 \\
(19.75)\end{array}$ & $\begin{array}{c}36.00 \\
(16.75)\end{array}$ & 0.007 \\
\hline Height (cm) & $\begin{array}{l}158.00 \\
(8.00)\end{array}$ & $\begin{array}{l}173.00 \\
(10.00)\end{array}$ & $<0.001$ \\
\hline Weight (kg) & $\begin{array}{c}87.80 \\
(21.75)\end{array}$ & $\begin{array}{l}97.70 \\
(25.80)\end{array}$ & $<0.001$ \\
\hline BMI (kg/m2) & $\begin{array}{c}35.40 \\
(10.30)\end{array}$ & $\begin{array}{l}32.50 \\
(7.77)\end{array}$ & 0.001 \\
\hline $\begin{array}{l}\text { Waist Circumference } \\
\text { (cm) }\end{array}$ & $\begin{array}{l}103.00 \\
(19.00)\end{array}$ & $\begin{array}{l}109.50 \\
(18.75)\end{array}$ & $<0.001$ \\
\hline $\begin{array}{l}\text { Hip Circumference } \\
\text { (cm) }\end{array}$ & $\begin{array}{l}119.00 \\
(18.00)\end{array}$ & $\begin{array}{l}114.01 \\
(13.00)\end{array}$ & $<0.001$ \\
\hline W/H ratio* & $0.86 \pm 0.06 *$ & $0.97 \pm 0.07 *$ & $<0.001$ \\
\hline BMR (kcal) & $\begin{array}{c}1574.50 \\
(250.5)\end{array}$ & $\begin{array}{c}2124.00 \\
(417.5)\end{array}$ & $<0.001$ \\
\hline BFP (\%) & $\begin{array}{l}41.40 \\
(8.50)\end{array}$ & $\begin{array}{l}28.00 \\
(8.28)\end{array}$ & $<0.001$ \\
\hline BFTW (kg) & $\begin{array}{c}36.50 \\
(16.80)\end{array}$ & $\begin{array}{c}27.70 \\
(14.85)\end{array}$ & $<0.001$ \\
\hline BLTW (kg) & $\begin{array}{l}50.90 \\
(7.85)\end{array}$ & $\begin{array}{c}71.40 \\
(12.65)\end{array}$ & $<0.001$ \\
\hline TBW (kg) & $\begin{array}{l}37.30 \\
(5.75)\end{array}$ & $\begin{array}{c}52.3 \\
(9.27)\end{array}$ & $<0.001$ \\
\hline VFR (\%) & $\begin{array}{l}10.00 \\
(6.00)\end{array}$ & $\begin{array}{l}12.00 \\
(8.75)\end{array}$ & $<0.001$ \\
\hline
\end{tabular}


The median and interquartile range values of laboratory findings in males and females are shown in Table 3. Hemoglobin, hematocrit and MCV, iron, ferritin, and vitamin D levels were significantly higher in males (p $<0.001$ for each). Platelet count ( $p<0,001)$ was significantly higher in females. The median values of insulin, insulin resistance, creatinine, üric acid, AST, ALT, and TG levels of male patients were significantly higher than female patients ( $p<0.001$ for each). HDL $(p<0.001)$ and TSH levels ( $p=0.002$ ) were significantly higher in females.

Table 3. Comparison of median and interquartile range values of biochemical findings in males and females

\begin{tabular}{|c|c|c|c|}
\hline Parameter & $\begin{array}{c}\text { Female } \\
(\mathrm{N}=780)\end{array}$ & $\begin{array}{c}\text { Male } \\
(\mathrm{N}=145)\end{array}$ & $\mathbf{p}$ \\
\hline WBC $(* 1000 / \mathrm{ul})$ & $7.40(2.30)$ & $7.60(2.25)$ & 0.060 \\
\hline $\mathrm{N} / \mathrm{L}$ ratio & $1.77(0.83)$ & $1.75(0.68)$ & 0.160 \\
\hline HB (g/dl) & $12.90(1.50)$ & $15.20(1.45)$ & $<0.001$ \\
\hline HCT (\%) & $38.80(3.90)$ & $45.20(3.80)$ & $<0.001$ \\
\hline $\operatorname{MCV}(\mathrm{fL})$ & $83.30(6.68)$ & $85.00(5.08)$ & $<0.001$ \\
\hline PLT $(* 1000 /$ ul) & $267.00(81.25)$ & $247.00(78.25)$ & $<0.001$ \\
\hline FPG (mg/dl) & $97.00(12.80)$ & $98.00(13.90)$ & 0.210 \\
\hline Insulin (uIU/ml) & $11.90(8.39)$ & $16.20(13.81)$ & $<0.001$ \\
\hline HOMA-IR & $2.80(2.14)$ & $3.80(3.63)$ & $<0.001$ \\
\hline Creatinine (mg/dl) & $0.65(0.15)$ & $0.860 .16)$ & $<0.001$ \\
\hline Üric Acid (mg/dl) & $4.60(3.25)$ & $6.10(4.15)$ & $<0.001$ \\
\hline AST (U/lt) & $18.80(7.20)$ & $23.80(11.30)$ & $<0.001$ \\
\hline ALT (U/lt) & $17.10(10.00)$ & $30.40(25.02)$ & $<0.001$ \\
\hline TC (mg/dl) & $189.00(51.75)$ & $198.00(48.75)$ & 0.600 \\
\hline HDL (mg/dl) & $52.80(17.00)$ & $43.00(14.15)$ & $<0.001$ \\
\hline LDL (mg/dl) & $110.00(45.00)$ & $116.00(38.68)$ & 0.840 \\
\hline TG (mg/dl) & $111.00(76.50)$ & $133.00(100.56)$ & 0.001 \\
\hline Iron (mg/dl) & $64.00(43.00)$ & $84.00(45.00)$ & $<0.001$ \\
\hline Ferritin (ng/ml) & $24.80(33.47)$ & $89.0(88.93)$ & $<0.001$ \\
\hline TSH $(\mu \mathrm{IU} / \mathrm{ml})$ & $1.90(1.69)$ & $1.60(1.42)$ & 0.002 \\
\hline Vitamin D (ng/ml) & $16.00(13.87)$ & $23.20(11.05)$ & $<0.001$ \\
\hline Vitamin B12(pg/ml) & $262.50(133.50)$ & $265.00(112.50)$ & 0.970 \\
\hline
\end{tabular}

Anthropometric and BIA measurements are shown in Table 4 with mean and standard deviation values according to groups. There was a significant difference in all variables ( $p<0.001$ ), between the groups. According to post-hoc analysis; the mean value of waist circumference, hip circumference, BMR values, mean values of BFP and BFTW, VFR values were significantly higher in group 1 than group 4 (p $<0.001$ for each). Individuals in group 1 have a significantly lower value $\mathrm{W} / \mathrm{H}$ ratio than the other groups $(\mathrm{p}<0.001 \mathrm{for}$ each). 
Table 4. Comparison of mean and standard deviation values of anthropometric variables according to groups

\begin{tabular}{|c|c|c|c|c|c|}
\hline Parameter & $\begin{array}{l}\text { Group } 1 \\
(n=232)\end{array}$ & $\begin{array}{l}\text { Group } 2 \\
(n=234)\end{array}$ & $\begin{array}{l}\text { Group } 3 \\
(n=234)\end{array}$ & $\begin{array}{l}\text { Group } 4 \\
(n=225)\end{array}$ & $\mathbf{p}$ \\
\hline Age (Year) & $34.50 \pm 11.81$ & $38.00 \pm 12.51$ & $42.00 \pm 11.40$ & $44.00 \pm 12.37$ & $<0.001^{b, c, d, d, f}$ \\
\hline Height (cm) & $161.50 \pm 7.64$ & $161.00 \pm 14.82$ & $159.00 \pm 8.20$ & $157.00 \pm 7.70$ & $<0.001^{\text {c,d,f,g }}$ \\
\hline Weight (kg) & $72.60 \pm 8.04$ & $83.80 \pm 10.72$ & $93.10 \pm 10.61$ & $108.57 \pm 14.40$ & $<0.001^{a}$ \\
\hline $\begin{array}{l}\text { Waist } \\
\text { Circumference } \\
\text { (cm) }\end{array}$ & $89.50 \pm 8.13$ & $101.00 \pm 8.52$ & $110.00 \pm 9.71$ & $117.00 \pm 11.20$ & $<0.001^{\mathrm{a}}$ \\
\hline $\begin{array}{l}\text { Hip } \\
\text { Circumference } \\
\text { (cm) }\end{array}$ & $107.00 \pm 5.45$ & $114.00 \pm 6.20$ & $120.70 \pm 6.11$ & $134.00 \pm 9.63$ & $<0.001^{\mathrm{a}}$ \\
\hline $\mathrm{W} / \mathrm{H}$ ratio & $0.84 \pm 0.07$ & $0.89 \pm 0.07$ & $0.89 \pm 0.08$ & $0.87 \pm 0.07$ & $<0.001^{b, c, d, g}$ \\
\hline BMR (kcal) & $1461.00 \pm 248.4$ & $1562.00 \pm 287.10$ & $1647.00 \pm 275.50$ & $1802.00 \pm 278.00$ & $<0.001^{\mathrm{a}}$ \\
\hline BFP (\%) & $33.50 \pm 5.90$ & $38.00 \pm 6.32$ & $42.50 \pm 4.82$ & $46.50 \pm 4.54$ & $<0.001^{a}$ \\
\hline BFTW (kg) & $23.50 \pm 4.63$ & $30.90 \pm 16.04$ & $39.10 \pm 5.04$ & $49.60 \pm 9.22$ & $<0.001^{a}$ \\
\hline BLTW (kg) & $47.80 \pm 8.21$ & $50.80 \pm 10.00$ & $53.30 \pm 9.67$ & $57.20 \pm 8.92$ & $\begin{array}{c}<0.001^{\text {b,c,d,f, }} \\
\text { g }\end{array}$ \\
\hline TBW (kg) & $35.00 \pm 6.01$ & $37.20 \pm 7.30$ & $39.00 \pm 7.08$ & $41.90 \pm 6.52$ & $\begin{array}{c}<0.001^{\text {b,c,d,f, }} \\
\text { g }\end{array}$ \\
\hline VFR (\%) & $6.00 \pm 2.11$ & $9.00 \pm 2.64$ & $11.00 \pm 2.83$ & $14.00 \pm 3.48$ & $<0.001^{\mathrm{a}}$ \\
\hline $\begin{array}{l}\text { group 1: pre-obese, group } \\
\text { a: all between groups, } \\
\text { b: group } 1 \text { to } 2 \text {, } \\
\text { c: group } 1 \text { to } 3, \\
\text { d: group } 1 \text { to } 4, \\
\text { e: group } 2 \text { to } 3 \text {, } \\
\text { f: group } 2 \text { to } 4 \text {, } \\
\text { g: group } 3 \text { to } 4 \text { difference }\end{array}$ & 1 obese, group 3: & obese, group 4: stage & & & \\
\hline
\end{tabular}

Table 5 shows the mean and standard deviation values and the level of significance between the groups. According to post-hoc analysis, individuals in group 2 have significantly higher values of Hb, HCT, MCV and lower value of PLT than other groups. Individuals in group 2 have significantly higher values of insülin, HOMAIR, creatinine, üric Acid, AST, ALT, TG, iron, ferritin and vitamin D and lower value of HDL than other groups $(\mathrm{p}<0.001$ for each). Individuals in group 1 have significantly higher values of TSH; individuals in group 2 have significantly lower values of TSH $(\mathrm{p}=0.002)$. 
Table 5. The mean and standard deviation values of biochemical findings according to groups

\begin{tabular}{|c|c|c|c|c|c|}
\hline Parameter & $\begin{array}{l}\text { Group } 1 \\
(n=232)\end{array}$ & $\begin{array}{l}\text { Group } 2 \\
(n=234)\end{array}$ & $\begin{array}{l}\text { Group } 3 \\
(n=234)\end{array}$ & $\begin{array}{l}\text { Group } 4 \\
(n=225)\end{array}$ & $\mathbf{p}$ \\
\hline Hgb (g/dl) & $12.90 \pm 1.12$ & $15.2 \pm 1.06$ & $13.10 \pm 1.42$ & $13.00 \pm 1.334$ & $<0.001$ \\
\hline HCT (\%) & $38.80 \pm 3.23$ & $45.2 \pm 2.85$ & $39.40 \pm 3.91$ & $39.10 \pm 3.84$ & $<0.001$ \\
\hline MCV (fL) & $83.30 \pm 6.07$ & $85.0 \pm 4.34$ & $83.70 \pm 5.83$ & $83.10 \pm 6.12$ & $<0.001$ \\
\hline PLT (x1000/ul) & $267.00 \pm 70.88$ & $247.0 \pm 59.58$ & $264.00 \pm 69.87$ & $272.00 \pm 69.34$ & $<0.001$ \\
\hline FPG (mg/dl) & $97.00 \pm 12.28$ & $98.0 \pm 17.71$ & $97.00 \pm 13.38$ & $98.00 \pm 17.92$ & 0.21 \\
\hline $\begin{array}{l}\text { Insulin } \\
\text { (uIU/ml) }\end{array}$ & $11.90 \pm 9.33$ & $16.2 \pm 12.52$ & $12.30 \pm 10.05$ & $13.30 \pm 12.71$ & $<0.001$ \\
\hline HOMA-IR & $2.80 \pm 2.55$ & $3.8 \pm 4.53$ & $2.90 \pm 2.92$ & $3.30 \pm 4.22$ & $<0.001$ \\
\hline $\begin{array}{l}\text { Creatinine } \\
\text { (mg/dl) }\end{array}$ & $0.65 \pm 0.37$ & $0.86 \pm 0.13$ & $0.67 \pm 0.35$ & $0.67 \pm 0.17$ & $<0.001$ \\
\hline $\begin{array}{l}\text { Uric Acid } \\
\text { (mg/dl) }\end{array}$ & $4.60 \pm 1.17$ & $6.10 \pm 1.21$ & $4.80 \pm 1.21$ & $5.10 \pm 1.27$ & $<0.001$ \\
\hline AST (U/lt) & $18.80 \pm 7.92$ & $23.81 \pm 13.50$ & $19.40 \pm 9.32$ & $19.50 \pm 9.15$ & $<0.001$ \\
\hline ALT (U/lt) & $17.10 \pm 11.53$ & $30.40 \pm 26.00$ & $18.20 \pm 16.11$ & $18.90 \pm 16.35$ & $<0.001$ \\
\hline TC (mg/dl) & $189.00 \pm 40.00$ & $189.00 \pm 37.72$ & $189.00 \pm 39.60$ & $190.00 \pm 37.91$ & 0.6 \\
\hline HDL (mg/dl) & $52.80 \pm 12.70$ & $43.00 \pm 11.12$ & $51.00 \pm 11.11$ & $50.00 \pm 12.10$ & $<0.001$ \\
\hline LDL (mg/dl) & $110.00 \pm 34.17$ & $116.00 \pm 30.12$ & $111.00 \pm 33.52$ & $112.00 \pm 33.42$ & 0.84 \\
\hline TG (mg/dl) & $111.00 \pm 64.01$ & $133.00 \pm 80.43$ & $113.00 \pm 67.31$ & $128.00 \pm 67.81$ & 0.001 \\
\hline Iron (mg/dl) & $64.00 \pm 31.51$ & $84.00 \pm 34.32$ & $67.00 \pm 32.43$ & $62.00 \pm 28.52$ & $<0.001$ \\
\hline $\begin{array}{l}\text { Ferritin } \\
(\mathrm{ng} / \mathrm{ml})\end{array}$ & $24.80 \pm 30.80$ & $89.00 \pm 102.44$ & $29.00 \pm 56.18$ & $33.50 \pm 39.21$ & $<0.001$ \\
\hline TSH $(\mu \mathrm{IU} / \mathrm{ml})$ & $1.90 \pm 1.68$ & $1.60 \pm 1.00$ & $1.80 \pm 1.59$ & $1.80 \pm 1.41$ & 0.002 \\
\hline $\begin{array}{l}\text { Vitamin D } \\
(\mathrm{ng} / \mathrm{ml})\end{array}$ & $16.00 \pm 12.72$ & $23.20 \pm 10.50$ & $17.00 \pm 12.44$ & $15.10 \pm 13.88$ & $<0.001$ \\
\hline $\begin{array}{l}\text { Vitamin } \\
\text { B12 }(\mathrm{pg} / \mathrm{ml})\end{array}$ & $262.50 \pm 124.53$ & $265.00 \pm 110.00$ & $263.00 \pm 122.31$ & $250.00 \pm 129.11$ & 0.97 \\
\hline
\end{tabular}

(Hgb: hemoglobin, HCT: hematocrit, MCV: mean erythrocyte volume, PLT: platelet count, FPG: fasting plasma glucose, HOMA-IR: insulin resistance, TC: total cholesterol)

\section{Discussion}

According to data from Turkey Health Survey conducted in 2016, the obesity rate was 23.9\% in females and $15.2 \%$ in males in Turkey. ${ }^{1}$ In our study, females were in the majority of our sample group in accordance with the prevalence of obesity in females in our country. Similar to the results of our study, an obesity study conducted in our country reported that $11 \%$ of the obese patient population were male ${ }^{7}$, and of the studies conducted in Switzerland ${ }^{8}$ and Portugal reported that $6 \%$ of the obese patient population was male. ${ }^{9}$ 
In our study, there was a significant difference in the distribution of men and women by groups and most of the females were in grade 3 obese group and most of the males were in grade 2 obese group. According to a study conducted by Saygin et al., pre-obesity is more common in both men and women. 10

Like our study, in the studies, it was observed that obesity increased after the age of 30 and peaked at 40 years of age. In our study, the median value age of women was higher than that of men. In our study, although the weight of men was higher than women's, BMI of women's was higher than men's. Many studies with similar results to our study are available in the literature. ${ }^{11,12}$ The reason for this condition is because of the body composition differences according to gender.

The amount of fat in the body is effective in the diagnosis of obesity. In BIA measurements, the fact that the percentage of body fat in women is $33 \%$ and in men is $25 \%$ is evaluated in favor of obesity. In our study, BFP was in favor of obesity in women (41.4\%) and men (28\%), but women's BFP value was higher than in men. The fact that the number of women is higher and their BMI values are higher than men may have led to this situation. Body fat weight (BFTW) was also higher in women in parallel with BFP. Visceral fat ratio (VFR) was higher in males backward to BFP. The results of our study are similar to the results of the literature. 12-14 Because of these differences between male and female sex, the use of prediction values according to gender is very important in follow-up and treatment, especially when evaluating patients in primary care.

In our study, the fasting plasma glucose levels of male and female individuals were similar and were not at the limit of hyperglycemia. Insulin level and insulin resistance were significantly higher in male patients. This may be related to the significant effect of visceral fat tissue on insulin secretion and insulin resistance, and the higher rate of visceral fat in males compared to females.

In our study, both sexes had normal cholesterol, HDL and TG levels, but LDL levels were higher than normal. While there was no significant difference between TC and LDL levels of women and men, HDL levels were higher in women than expected. This finding is similar to the studies in the literature. ${ }^{14-17}$ In our study, the TG levels of the males were higher than the females. In many studies, TG was found to be higher in males. 1-9 Abdominal obesity is more frequent in men and VFR height may be some factors in this condition.

In our study, PLT, TSH and HDL levels were lower, insulin, HOMA-IR, uric acid, AST, ALT and TG levels were found to be significantly higher in males compared to females. In line with these results, it is useful to be more careful in terms of metabolic complications in the follow-up of male obesity.

A decrease in basal metabolic rate, decrease in mobility and hormonal changes as age increase may be effective in increasing obesity. In a study conducted by Çayır et al., the highest obesity rates were observed at 61 years of age and above, and the increase in age increased with obesity. ${ }^{18}$ In some studies, all groups of obese patients' 
ages were found as similar; ${ }^{11,19}$ however, some studies also indicate that obesity was increase with age. ${ }^{20-22}$ In our study, we found that obesity was increase with the mean age.

In our study, median values of waist circumference and hip circumference, the W/H ratio, VFP and VFR were significantly increased with the increase in obesity. This may be the reason why the body's fat tissue and weight increase with the increase in obesity degree.

WBC and N/L ratios showed difference between groups and increased according to obesity. In this case, the relationship between obesity and inflammation can be effective. An increase in obesity leads to an increase in adipose tissue and associated inflammatory response.

Especially abdominal obesity has negative effects on APG, insulin and HOMA-IR. ${ }^{23}$ In our study, APG was significantly lower in the pre-obese group compared to stage 2 and stage 3 obese groups. The results of other studies also support our study. ${ }^{21,24,25}$

In our study, creatinine levels were significantly different in stage 1 obese patients compared to stage 2 and stage 3 obese patients. According to this, obesity severity and duration are effective in the effects of obesity on renal functions.

Similar to the studies in literature, uric acid levels were significantly lower in the pre-obese group compared to the obese groups in this study. ${ }^{25,26}$ The relationship between high uric acid level and obesity and obesityrelated diseases was shown in studies. ${ }^{21,22}$ Obesity may decrease the renal excretion of uric acid or increase its reabsorption. ${ }^{27}$

One of the major complications of obesity is lipid metabolism disorders. HDL decreases and LDL and TG increase with the effect of obesity. This is also a risk factor for cardiovascular diseases. In our study, HDL levels were higher in the pre-obese group than in stage 2 and stage 3 obese patients; the level of LDL was lower in the pre-obese group compared to stage 1 and stage 2 obese and the levels of TG were lower in stage 1 obese compared to stage 3 obese. The results of our study are consistent with the studies in the literature. 19,22,24

In our study, iron levels in stage 1 obese group were higher than those in stage 2 and stage 3 obese groups. Ferritin levels were lower in the pre-obese group compared to stage 1 and stage 3 obese groups. In recent years, it has been widely accepted that increased serum ferritin levels are the result of obesity-induced chronic inflammatory reaction and are not merely indicative of an increase in iron stores. $28,29,30$ This result in our study may be related to this situation. 
Studies investigating the relationship between vitamin D and obesity in the literature are cross-sectional and the results are controversial. ${ }^{20}$ To explain the relationship between obesity with vitamin D and TSH, larger and prospective studies can be performed.

These results indicate that metabolic deterioration started with the transition from pre-obese phase to the obese phase. Therefore, counseling should be given to the patients before the development of obesity or at preobese phase.

In conclusion, the effects of obesity on body components and metabolic parameters vary according to gender and obesity. Therefore, it is important to have an individualistic and holistic approach in the evaluation, followup and treatment of patients. The negative effects of obesity on health are associated with an increase in fat tissue in the body rather than weight gain. Therefore, determining the amount of fat tissue and monitoring of the body is very important in reducing these negative effects. BIA is a reliable, easy, noninvasive and costeffective method of detecting body components, especially fat tissue. The use of BIA in the evaluation of obesity in primary care, which is the first place where patients apply and which is primarily responsible for preventive health services, is very useful. In addition, primary care physicians should be very careful about comorbid diseases and complications (hypertension, metabolic syndrome, hyperlipidemia) caused by obesity.

The most effective step for obesity is to prevent the development of obesity. For this reason, individuals with normal weight should be encouraged to maintain their current weight by giving counseling about healthy lifestyle habits. Patients in pre-obese stage should be provided with necessary recommendations and treatments and returned to their normal weight. All patients should be advised about diet and exercise; medical treatment should be arranged in the required patients and treatment processes of all patients should be supported by motivational interviewing. In addition, it is necessary to inform the public more about obesity and its complications, to raise awareness and to implement social projects that prevent obesity.

\section{References}

1. Türkiye Sağlık Araştırması 2016, Türkiye İstatistik Kurumu, http://www.tuik.gov.tr, (Access date:19.03.2020)

2. World Health Organization. Obesity: preventing and managing the global epidemic. Technical report 894. Geneva: WHO. 2000;256.

3. Türkiye endokrinoloji ve metabolizma derneği, Obezite tanı ve tedavi klavuzu. Ankara; 2014:25-7.

4. Koroner Kalp Hastalığı Korunma ve Tedavi Kılavuzu. İstanbul: Türk Kardiyoloji Derneği; 2002.

5. Sağlık Bakanlığı Temel Sağlık Hizmetleri Genel Müdürlüğü Gıda Güvenliği Daire Başkanlığı, 'Sağlıklı Beslenelim, Kalbimizi Koruyalım' Projesi Araştırma Raporu, Ankara: Gürler Matbaası; 2004.

6. Serter R. Obezite Atlası. Ankara: Karakter Color Basımevi; 2004.

7. Aladağ N, Ciğerli Ö, Topsever P, Topallı R, Görpelioğlu S, Filiz TM. Değirmendere Aile Hekimliği Polikliniğine Başvuran Erişkin Hastalarda Obezite Sıklığı ve Eşlik Eden Hastalıklarla İlişkisi: Bir Olgu Kontrol Çalışması. Türkiye Aile Hekimliği Dergisi 2003;7(3):117-21. 
8. Schutz Y, Woringer V. Obesity in Switzerland: a critical assessment of prevalence in children and adults.Int J Obes Relat Metab Disord 2002 Sep;26 Suppl2:3-11.

9. Marques-Vidal P, Llobet S, Carvalho Rodrigues JA, Halpern MJ. Cardiovascular risk factor levels in Portuguese students. Acta Cardiol 2001 Apr;56(2):97- 101.

10. Saygın M, Öztürk Ö, Akbulut S, Kılınç F, Saygın RR. Süleyman Demirel Üniversitesi Tıp Fakültesi Hastanesi diyet polikliniğine başvuran hastalarda obezite prevelansı. Med J SDU/SDÜ Tıp Fak Derg. 2015;22(3):53-9

11. Keskin S, Sayalı E, Temeloğlu E, Ekizoğlu İ. Obezite ve inflamasyon. Turkiye klinikleri journal of medical sciences. 2005;25(5):636-41.

12. Heyward, V. H., Wagner, D. R. Applied Body Composition Assessment, (Second Edition), USA, Human Kinetics, 2004;28-47.

13. Van der Kooy K, Leenen R, Seidell JC, Deurenberg P, Droop A, Bakker CJ. Waist-hip ratio is a poor predictor of changes in visceral fat. The American journal of clinical nutrition. 1993;57(3):327-33.

14. Snijder M, Visser M, Dekker J, Seidell J, Fuerst T, Tylavsky F, et al. The prediction of visceral fat by dual-energy X-ray absorptiometry in the elderly: a comparison with computed tomography and anthropometry. International journal of obesity. 2002;26(7):984.

15. TEMD Obezite, Dislipidemi, Hipertansiyon Çalışma Grubu, TEMD DİSLİPIDEMİ TANI VE TEDAVİ KILAVUZU 2019, http://www.turkendokrin.org/files/LIPID2019_web.pdf , (Access date: 29.03.2020).

16. Kobayashi J, Murano S, Kawamura I, et al. The relationship of percent body fat by bioelectrical impedance analysis with blood pressure, and glucose and lipid parameters. Journal of atherosclerosis and thrombosis. 2006;13(5):221-6.

17. Park BJ, Shim JY, Lee HR, Jung DH, Lee JH, Lee YJ. The relationship of platelet count, mean platelet volume with metabolic syndrome according to the criteria of the American Ass ociation of Clinical Endocrinologists: a focus on gender differences. Platelets. 2012;23(1):45-50.

18. Çayır A, Atak N, Köse SK. Beslenme ve Diyet Kliniğine Başvuranlarda Obezite Durumu ve Etkili Faktörlerin Belirlenmesi. Ankara Üniversitesi Tıp Fakültesi Mecmuası, 2011; 64(1).

19. Kutlutürk F, Öztürk B, Yıldırım B, et al. Obezite prevalansı ve metabolik risk faktörleri ile ilişkisi: Tokat ili prevalans çalışması. Turkiye Klinikleri Journal of Medical Sciences. 2011;31(1):156-63.

20. Vilarrasa N, Maravall J, Estepa A, Sanchez R, Masdevall C, Navarro M, et al. Low 25-hydroxyvitamin D concentrations in obese women: their clinical significance and relationship with anthropometric and body composition variables. Journal of endocrinological investigation. 2007;30(8):653-8.

21. Gómez-Ambrosi J, González-Crespo I, Catalán V, et al. Clinical usefulness of abdominal bioimpedance (ViScan) in the determination of visceral fat and its application in the diagnosis and management of obesity and its comorbidities. Clinical Nutrition. 2018;37(2):580-9.

22. Aktaş G, Alçelik A, Şavlı H, et al. Obez ve fazla kilolu bireylerde ürik asit ve gamma glutamil transferaz düzeylerinin değerlendirilmesi. Bozok Tıp Dergisi. 2013;3(3)

23. Kopelman PG. Hormones and obesity. Bailliere's Clinical Endocrinology and metabolism 1994;8 (3):549-60.

24. Bahadır A, Baltacı D, Türker Y, et al. Is the neutrophil-to-lymphocyte ratio indicative of inflammatory state in patients with obesity and metabolic syndrome? Anatolian journal of cardiology. 2015;15(10):816.

25. Nalbant A, Konuk S. Obezite ile D vitamini, C-reaktif protein, hemogram parametreleri ve kan grupları arasındaki ilişki. Ortadoğu Tıp Dergisi.10(1):20-5.

26. Saraç F, Saydam G, Tüzün M, Kabalak T, Yılmaz C. Obezitede trombosit fonksiyonları. Turkish Journal of Endocrinology and Metabolism. 2003;7(2):69-72

27. Oliveira EP, Burini RC. High plasma uric acid concentration: causes and consequences. Diabetol Metab Syndr. 2012;4:12.

28. Altunoğlu E, Müderrisoğlu C, Erdenen F, Ülgen E, Ar MC. The impact of obesity and insulin resistance on iron and red blood cell parameters: a single center, cross-sectional study. Turkish Journal of Hematology. 2014;31(1):61. 
29. Kaner G. Hafif şişman ve şişman kadınlarda demir yetersizliği anemisi, beslenme örüntüsü ile kronik inflamasyon belirteçleri ve diyet tedavisinin etkinliğinin belirlenmesi. T.C. Hacettepe Üniversitesi, Sağlık Bilimleri Enstitüsü Beslenme ve Diyetetik Anabilim Dalı, Doktora Tezi, Ankara 2013.

30. Özbey Z, Sönmez CI, Ayhan Başer D. The Relationship Between The Level Of Serum Ferritin And Metabolic Parameters In Obese Patients. Acta Medica Mediterranea, 2020,36:217. 